\title{
PENINGKATAN MEMAHAMI TEKS CERITA SISWA MENGGUNAKAN METODE PQ4R
}

\author{
SUSANA DEWI DAN MUHAMMAD SAIHU
}

SMPN 1 Martapura

Jalan A. Yani KM 39 No.44 Martapura

email: susanadewi017@gmail.com

\section{SDN 1 Sari Mulya}

Jalan Ahmad Yani, Sungai Loban, Tanah Bumbu email: saihujaderi@gmail.com

\begin{abstract}
ABSTRAK
Pelaksanaan pembelajaran membaca wacana, Siswa sulit memahami Teks Cerita Inspiratif dengan menjawab pertanyaan bacaan yang isinya memuat garis besar isi bacaan.Alternatif untuk memecahkan permasalahan ini dipilih metode yang sesuai yaitu Metode PQ4R. Dengan metode ini siswa dapat meningkatkan kemampuan memahami Teks Cerita Inspiratif .Tujuan dari penelitian ini adalah "untuk mengetahui Peningkatan Kemampuan Memahami Teks Cerita Inspiratif Dengan Metode PQ4R siswa IX-C SMP Negeri 1 Martapura Kabupaten Banjar Semester Genap tahun pelajaran 2018/2019". hasil penelitian dapat disimpulkan hal hal berikut : Peningkatan kemampuan memahami Teks Cerita Inspiratif dapat dilihat dari Hasil pengamatan aktivitas meningkat dari siklus I ke siklus II. Komponen yang berkualifikasi cukup pada siklus sbeelumnya meningkat menjadi kualifikasi cukup baik, begitu juga dari kualifikasi cukup baik menjadi baik.Hasil kemampuan siswa menyelesaikan LKS meningkat dari siklus I ke siklus II. Hasil rata-rata tes pemahaman terhadap Teks Cerita Inspiratif meningkat dari 14,08 dari siklus I ke siklus II (dari 70,31 menjadi 84,38). Ketuntasan belajar sebagai indikator peningatan pemahaman Teks Cerita Inspiratif secara klasikal juga meningkat 31,04\% dari siklus I ke siklus II (dari 59,28 menjadi 90,32\%).
\end{abstract}

Kata kunci: memahami teks cerita inspiratif, metode pq4r

\section{PENDAHULUAN}

Salah satu cara untuk meningkatkan kemampuan berpikir dan bernalar serta kemampuan memperluas wawasan dasar untuk dapat menulis dan berhitung. Selain itu diperlukan juga teknik pembelajaran dan kegiatan membaca disamping memperhatikan materi dan isi bacaan. (Ambary, $2006: 20)$.

Di sekolah, tingkat kemampuan siswa untuk memahami isi bacaan masih kurang. Hal ini terbukti dengan adanya gejala bahwa pembelajaran masih dilaksanakan dengan membaca secara bergantian melalui perhatian terhadap kalimat-kalimat yang dibaca oleh siswa yang lain, menjawab 
pertanyaan sambil melihat bacaan, dan jawabannya sama dengan apa yang tersurat dalam bacaan, sehingga pada hasil belajar belum optimal danbelummenunjukkan penguasaan materi yang dijelaskan guru.

Kenyataan yang terjadi pada pelaksanaan pembelajaran membaca wacana, siswa secara bergilir membaca wacana sedangkan siswa yang lain menunggu giliran dengan kegiatan pasif hanya mendengarkan dan memperhatikan wacana yang ada di depannya. Ketika tiba gilirannya barulah siswa yang ditunjuk untuk membaca sesuai kalimat yang menjadi bagiannya.Siswa sulit memahami Teks Cerita Inspiratif dengan menjawab pertanyaan bacaan yang isinya memuat garis besar isi bacaan.Bahkan dalam sebuah bacaan dapat memuat garis besar yang saling berkaitan antar paragraph.

Dalam hal ini, untuk mengetahui sejauh mana kegiatan guru dan siswa dalam pembelajaran membaca yang bertujuan untuk memperoleh pemahaman, maka diadakan pengamatan pembelajaran membaca Teks Cerita Inspiratif pada siswa Kelas IX SMP Negeri 1 Martapura Kabupaten Banjar.

Alternatif untuk memecahkan permasalahan ini dipilih metode yang sesuai yaitu Metode PQ4R.Dengan metode ini siswa dapat meningkatkan kemampuan memahami Teks Cerita Inspiratif.Banyak terjadi dalam pembelajaran membaca yang dilakukan adalah membaca secara bergilir tanpa kegiatan aktif siswa lainnya.Hal inilah yang akan menjadi fokus penelitian yakni upaya meningkatkan kemampuan memahami Teks Cerita Inspiratif dengan Metode PQ4R dan hasil yang yang didapatkan dalam meningkatkan kemampuan memahami teks cerita inspiratif melalui metode PQ4R

\section{METODE}

Penelitian yang dilakukan adalah penelitian pendidikan yang merupakan Penelitian Tindakan Kelas (PTK).PTK ini adalah penelitian reflektif yang dilaksanakan secara siklis (berdaur) oleh guru di dalam kelas.Dikatakan demikian PTK mulai tahapan perencanaan, tindakan, pengamatan, dan refleksi yang ditujukan untuk memecahkan masalah dan mencobakan hal-hal baru demi peningkatan kualitas pembelajaran.PTK ini adalah PTK individual yang dilakukan oleh seorang guru.

Penelitian ini dilakukan di SMP Negeri 1 Martapura Kabupaten Banjar pada mata pelajaran Bahasa Indonesia pada semester Genap tahun pelajaran 2018/2019 pada Kompetensi Dasar "Memahami teks Cerita Inspiratif" kompetensi dasar menemukan kalimat utama pada tiap paragraph . 
Penelitian yang dimaksud yaitu "Peningkatan Kemampuan membaca Teks Cerita Inspiratif Dengan Metode PQ4R Siswa Kelas IX-C SMP Negeri 1 Martapura Kabupaten Banjar Semester Genap tahun pelajaran 2018/2019”. Subjek penelitian dalam hal ini siswa kelas IX-C yang jumlahnya 31 siswa.Adapun nama-nama subjek penelitian seperti table di bawah ini.

Secara garis besar, langkah-langkah dalam penelitian tindakan kelas meliputi perencanaan (plan), tindakan (action), pengamatan (observation), dan refleksi (reflection).Kemmis dan Mc Taggart, dalam Syaiful Rahman, 2006). Keempat langkah pokok in membentuk satu siklus.Penelitian tindakan merupakan strategi yang berkelanjutan.Siklus yang terdiri dari empat langkah tersebut diulang sehingga membentuk spiral; perumusan kembali rencana, perbaikan tindakan, pencarian fakta lebih banyak, dan analisis ulang.Spiral atau siklus itu berulang terus menerus sampai maslah yang diteliti dapat dipecahkan/diatasi dengan baik.

Tes Akhir Siklus

Peneliti melakukan penjumlahan nilai yang diperoleh siswa, yang selanjutnya dibagi dengan jumlah siswa yang ada di kelas tersebut sehingga diperoleh rata-rata tes akhir siklus dapat dirumuskan :

$$
\overline{\mathrm{X}}=\frac{2 X}{2 . N}
$$

Dengan $\bar{X}=$ nilai rata-rata

$\Sigma \mathrm{X}=$ jumlah semua nilai siswa

$\Sigma \mathrm{N}=$ jumlah siswa

Untuk Ketuntasan Belajar

Ada dua kategori ketuntasan belajar yaitu secara perorangan dan secara klasikal,

a) Seorang siswa telah tuntas belajar bila telah mencapai skor 70 (70\%), dan

b) Kelas disebut tuntas belajar bila dikelas tersebut terdapat $85 \%$ yang telah mencapai daya serap lebih atau sama dengan $70 \%$. Untuk menghitung prosentase ketuntasan belajar digunakan rumus sebagai berikut :

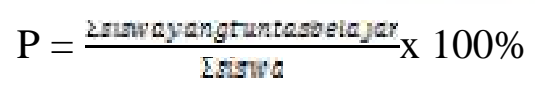

\section{HASIL DAN PEMBAHASAN}

\section{Membaca}

Menurut Suyatno (2004 : 17), membaca adalah pengolahan bacaan secara kritis, kreatif yang dilakukan dengan tujuan memperoleh pemahaman yang bersifat menyeluruh tentang bacaan itu, dan penilaian terhadap keadaan, nilai fungsi dan dampak bacaan itu. 
Menurut Syafi'ie (2006 : 63) bahwa membaca adalah suatu proses yang sangat rumit dan unik pula sifatnya, kerumitannya terutama terletak pada banyaknya serta beraneka ragamnya faktor yang bekerja dalam proses membaca itu, dan taut bertautnya faktor yang satu dengan yang lainnya. Keunikannya terletak pada relative berbeda-bedanya proses membaca itu berlangsung pada setiap pembaca.

Dengan adanya kerumitan serta keunikan tersebut, maka pengajaran membaca di sekolah perlu adanya metode-metode yang cocok untuk siswa sesuatu dengan tingkatannya. Pemahaman siswa terhadap suatu bacaan harus terus ditingkatkan guna mencapai tujuan yang diinginkan yakni memahami isi bacaan sesuai dengan apa yang tersurat maupun yang tersirat.

\section{Membaca Pemahaman}

Nuryatim HS (2004 : 43) kemampuan membaca siswa SMP memang belum banyak karena tidak adanya tujuan khusus dari kegiatan membaca yang telah dilakukan, hanya sebatas menerima apa adanya dari guru atau perintahnya. Oleh karena itu perlu keterampilan khusus untuk melatih keterampilan litearalnya dalam proses memahami Teks Cerita Inspiratif.

Keterampilan literal tersebut meliputi :
a. Mengenal kata
b. Mengenal kalimat
c. Mengenal paragraph
d. Mengenal unsure detail
e. Mengenal unsure perbandingan
f. Mengenal unsur urutan
g. Mengenal unsure sebab-akibat
h. Mampu menjawab pertanyaan $(5 \mathrm{~W} 1 \mathrm{H})$
i. Melatih menyatakan kembali unsure perbandingan
j. Melatih kembali unsure urutan
k. Menyatakan kembali unsure sebab akibat berikut:
a. Komponen pertama pengembangan kosakata.
b. Komponen kedua disebut pemahaman literal
c. Komponen ketiga disebut pemahaman inferensial,
d. Komponen keempat adalah membaca kritis atau evaluative,

Membaca pemahaman meliputi beberapa komponen, komponen tersebut antara lain sebagai 
e. Komponen terakhir, apresiasi menyangkut kepekaan emosi dan estetika (seni) anak atas materi wacana.

Secara lebih operasional, membaca pemahaman menuntut kemampuan sebagai berikut: (1) mengingat pokok pikiran wacana tertulis, (2) mengingat urutan kejadian atau pendapat; (3) mencari jawaban atas pertanyaan rinci isi wacana tertulis; (4) mengikuti petunjuk tertulis, (5) mencari hubungan sebab akibat; (6) membuat kesimpulan berdasarkan wacana tertulis; (7) mengetahui kejanggalan isi wacana; (8) materi bersifat factual atau fiktif; (9) memanfaatkan daftar isi dan indeks buku; (10) membaca table, diagram atau peta; dan (11) memanfaatkan berbagai makna suatu kata.

\section{Pengajaran Membaca Dalam Kurikulum}

Membaca merupakan aktivitas auditif dan visual untuk memperoleh makna symbol yang berupa huruf dan angka. Aktivitas ini meliputi dua proses yaitu proses docoding, juga dikenal dengan istilah membaca teknis dan proses pemahaman. Membaca teknis adalah proses pemahaman atas hubungan antara huruf (grafim) dan bunyi (morfim) atau menterjemahkan kata-kata tercetak menjadi bahasa lisan atau sejenisnya. Mengucapkan (baik dalam hati maupun bersuara) kata "kucing makan" yang tercetak merupakan membaca teknis. Sedangkan pemahaman merupakan proses menangkap makna kata-kata yang tercetak. Pada waktu melihat tulisan "kucing makan", pembaca akan mengetahui bahwa yang makan bukan anjing dan bahwa kucing dalam tulisan tersebut tidak sedang tidur.

Berdasarkan hasil penelitian, lebih dari $10 \%$ murid sekolah dasar mengalami kesulitan membaca. Kesulitan membaca menjadi penyebab utama kegagalan anak di sekolah.Hal ini dapat dipahami karena membaca merupakan salah satu bidang akademik dasar, selain menulis dan berhitung.Kesulitan membaca juga menyebabkan anak merasa rendah diri, tidak termotivasi untuk belajar, dan sering juga mengakibatkan timbulnya perilaku menyimpang pada anak yang bersangkutan.

Anak-anak berkesulitan membaca harus ditanagani sedini mungkin, agar masalah yang dihadapi tidak semakin membesar dan berlarut-larut.Langkah penanganan anak-anak yang mengalami kesulitan membaca tersebut meliputi pengukuran (assessment) dan tahap penanganan (treatment).Assessment bertujuan untuk mengetahui secara pasti jenis masalah yang dihadapi anak.Berdasarkan hasil assessment inilah guru diharapkan dapat menyusun program penanganan yang sesuai.Untuk dapat mengadakan assessment dan menyusun program yang baik, guru perlu 
mengatahui keterampilan yang terkait. Materi membaca meliputi keterampilan membaca teknis dan membaca pemahaman.

\section{Kemampuan Memahami Bacaan}

Minat baca dan kegemaran membaca seseorang bukan sifat yang dibawa atau datang dengan sendirinya.Seseorang secara ilmiah minat itu harus ditumbuhkan, dipelihara dan ditingkatkan selama orang (anak) yang bersangkutan tumbuh dan berkembang.Minat baca anak ditumbuhkan melalui kegiatan secara terstruktur mulai memahami kode sampai menginterpretasi (Buananta, 2005).

Nurhadi (2005: 26) berpendapat bahwa membaca adalah sebuah keterampilan.Setiap orang berbeda kemampuan membacanya.Namun yang jelas semua orang dapat meningkatkan kemampuan membacanya itu.

Gray (dalam Martutik, 2005: 14) mendefinisikan membaca pemahaman melalui tiga tipe yaitu (1) kemampuan membaca tersurat, (2) kemampuan membaca tersirat, dan (3) kemampuan membaca tersorot. Sedangkan Nurhadi (2005 : 26) membagi kegiatan membaca pemahaman menjadi tiga tingkatan yaitu kemampuan membaca literal, kritis dan kreatif. Dari kedua pendapat tersebut sama hanya berbeda istilah. Sedangkan untuk meningkatkan kemampuan membaca, setiap orang harus melalui ketiga tingkatan tersebut.

\section{Metode PQ4R}

Menurut Weintein dan Meyer dana Nur (2006 : 5) pengajaran yang baik meliputi mengajaran siswa bagaimana belajar, bagaimana mengingat, bagaimana berfikir dan bagaimana memotivasi dir mereka sendiri. Pengajaran strategi belajar berdasarkan pada dalili bahwa keberhasilan siswa sebagian besar bergantung pada kemahiran untu belajar mandiri dan memonitor belajar mereka sendiri.Hal inilah yang menjadikan strategi belajar mutlak diajarkan kepada siswa tersendiri mulai dari kelas empat SD dan terus berlanjut sampai sekolah menengah dan pendidikan tinggi.

Secara umum strategi mempunyai penegrtian garis-garis besar haluan untuk bertindak dalam usaha mencapai sasaran yang telah ditentukan.Dihubungkan dengan belajar mengajar, strategi bisa diartikan sebagai pola-pola umum kegiatan guru dan anak didik dalam perwujudan kegiatan belajar mengajar untuk mencapai tujuan yang telah digariskan.

Strategi PQ4R (Preview, Question, Read, Recite and Review) merupakan salah satu bagian dari strategi elaborasi. Strategi elaborasi sendiri merupakan proses penambahan penemuan sehingga informasi baru akan bertambah dan lebih bermakna. Metode ini membantu pemindahan informasi 
baru dari memori jangka pendek ke informasi jangka panjang, melalui penciptaan gabungan dan hubungan antara informasi baru dan apa yang telah diketahui.

Gie (dalam Suyatno, 2004 : 12) membaca dapat dipandang sebagai sebuah proses interaktif antara bahasa dan pikiran. Sebagai proses interaktif maka keberhasilan membaca akan dipengaruhi oleh factor pengetahuan yang melatarbelakangi dan strategi membaca yang digunakan.

Konsep ekosistem dan interaksinya dapat dilatihkan dengan cara membca buku teks, maka peneliti mencoba menerapkan PQ4R untuk memudahkan siswa memahmi konsep tersebut. (Arends, 197), PQ4R juga dikenal banyak membantu siswa dalam memahami dan mengingat materi yang mereka baca.PQ4R ini didasarkan pada PQRST dan SQ3R.

\section{Langkah-Langkah Memahami PQ4R}

Metode SQ3R yang dicetuskan oleh Francis Robinson tahun 1941, yang membuat perubahan besar dalam bentuk perkembangan metodologi belajar (Nur, 2005).

Sebagai elaborasi, metode PQ4R lebih menekankan pada keterampilan pokok pertama yang harus dikembangkan dan dikuasai oleh para siswa yakni membaca buku pelajaran dan bacaan tambahan lainnya.

Thomas dan Robinson (1972), dalam Arends (1997 : 25) metode PQ4R didasarkan pada strategi PQRST dan SQ3R. adapun langkah-langkah yang harus dilakukan dalam metode PQ4R ini adalah sebagai berikut :

a. Preview

b. Question

c. Read

d. Reflect

e. Recite

f. Review

Table 1 Langkah-langkah Pemodelan Pembelajaran dengan Strategi Belajar PQ4R

\begin{tabular}{|c|c|c|}
\hline $\begin{array}{c}\text { Langkah- } \\
\text { langkah }\end{array}$ & Tingkah Laku Guru & Aktivitas Siswa \\
\hline $\begin{array}{c}\text { Langkah } 1 \\
\text { Preview }\end{array}$ & $\begin{array}{l}\text { a. Memberikan bahan bacaan kepada } \\
\text { siswa untuk dibaca } \\
\text { b. Menginformasikan kepada siswa } \\
\text { bagaimana menemukan ide } \\
\text { pokok/tujuan pembelajaran yang } \\
\text { hendak dicapai }\end{array}$ & $\begin{array}{l}\text { Membaca selintas dengan cepat } \\
\text { untuk menemukan ide pokok/tujuan } \\
\text { pembelajaran yang hendak dicapai }\end{array}$ \\
\hline
\end{tabular}




\begin{tabular}{|c|c|c|}
\hline $\begin{array}{l}\text { Langkah } 2 \\
\text { Question }\end{array}$ & $\begin{array}{l}\text { a. Menginformasikan kepada siswa } \\
\text { agar memperhatikan makna dari } \\
\text { bacaan. } \\
\text { b. Memberikan tugas kepada siswa } \\
\text { untuk membuat pertanyaan dari ide } \\
\text { pokok yang ditemukan dengan } \\
\text { menggunakan kata-kata, apa, } \\
\text { mengapa, siapa dan bagaimana }\end{array}$ & $\begin{array}{l}\text { a. Memperhatikan penjelasan guru } \\
\text { b. Menjawab pertanyaan yang telah } \\
\text { dibuatnya. }\end{array}$ \\
\hline $\begin{array}{l}\text { Langkah } 3 \\
\text { Read }\end{array}$ & $\begin{array}{l}\text { Memberikan tugas kepada siswa } \\
\text { untuk membaca } \\
\text { menggapi/menjawab pertanyaan yang } \\
\text { telah disusun sebelumnya }\end{array}$ & $\begin{array}{l}\text { Membaca secara aktif sambil } \\
\text { memberikan tanggapan terhadap apa } \\
\text { yang telah dibaca dan menjawab } \\
\text { pertanyaan yang dibuatnya }\end{array}$ \\
\hline $\begin{array}{c}\text { Langkah } 4 \\
\text { Reflect }\end{array}$ & $\begin{array}{l}\text { Mensimulasikan/menginformasikan } \\
\text { materi yang ada pada bahan bacaan }\end{array}$ & $\begin{array}{l}\text { Bukan hanya sekedar menghafal dan } \\
\text { mengingat materi pelajaran tetapi } \\
\text { mencoba memecahkan masalah dan } \\
\text { informasi yang diberikan oleh guru } \\
\text { dengan pengetahuan yang telah } \\
\text { diketahui melalui bahan bacaan }\end{array}$ \\
\hline $\begin{array}{c}\text { Langkah } 5 \\
\text { Recite }\end{array}$ & $\begin{array}{l}\text { Meminta siswa membuat intisari dari } \\
\text { seluruh pembahasan pelajaran yang } \\
\text { dipelajari hari ini }\end{array}$ & $\begin{array}{l}\text { a. Menanyakan dan menjawab } \\
\text { pertanyaan-pertanyaan. } \\
\text { b. Melihat catatan-catatan atau } \\
\text { intisari yang dibuat sebelumnya } \\
\text { c. Membuat intisari dari seluruh } \\
\text { pembahasan }\end{array}$ \\
\hline $\begin{array}{c}\text { Langkah } 6 \\
\text { Review }\end{array}$ & $\begin{array}{l}\text { a. Menugaskan siswa membaca } \\
\text { intisari yang dibuatnya dari ide } \\
\text { pokok yang ada dalam benaknya. } \\
\text { b. Meminta siswa membaca kembali } \\
\text { bahan bacaan, jika masih belum } \\
\text { yakin dengan jawabannya }\end{array}$ & $\begin{array}{l}\text { a. Membaca intisari yang telah } \\
\text { dibuatnya } \\
\text { b. Membaca kembali bahan bacaan } \\
\text { siswa jika masih belum yakin } \\
\text { akan jawaban yang telah } \\
\text { dibuatnya }\end{array}$ \\
\hline
\end{tabular}

Table 2 Langkah-langkah Penerapan Pembelajaran Metode PQ4R

\begin{tabular}{|c|c|c|}
\hline No & Aktivitas Guru & Aktivitas Siswa \\
\hline I & $\begin{array}{l}\text { PENDAHULUAN } \\
\text { a. Menyampaikan tujuan } \\
\text { pembelajaran } \\
\text { b. Mengaitkan pelajaran yang } \\
\text { akan dipelajari dengan } \\
\text { penegtahuan siswa } \\
\text { c. Memotivasi siswa }\end{array}$ & $\begin{array}{l}\text { a. Dalam pelaksanaan KBM guru menginformasikan } \\
\text { tujuan pembelajaran secara lisan, dan menuliskan } \\
\text { TPK yang akan dicapai } \\
\text { b. Guru mengingatkan kembali materi-materi } \\
\text { sebelumnya yang relevan dengan materi yang } \\
\text { akan disampaikan } \\
\text { c. Guru memotivasi siswa dengan memperlihatkan } \\
\text { fenomena tervisualisasi }\end{array}$ \\
\hline II & $\begin{array}{l}\text { KEGIATAN INTI } \\
\text { a. Mempresentasikan materi } \\
\text { b. Pemodelan strategi belajar } \\
\text { metode PQ4R }\end{array}$ & $\begin{array}{l}\text { a. Sebelum pelaksanaan pengajaran strategi belajar, } \\
\text { guru mempresentasikan sedikit gambaran umum } \\
\text { dari materi yang akan dipelajari } \\
\text { b. Guru memodelkan keterampilan strategi belajar }\end{array}$ \\
\hline
\end{tabular}




\begin{tabular}{|c|c|c|}
\hline & $\begin{array}{l}\text { c. Pemberian latihan terbimbing } \\
\text { d. Umpan balik } \\
\text { e. Pemberian latihan mandiri }\end{array}$ & $\begin{array}{l}\text { metode PQ4R, langkah perlangkah pada tiap-tiap } \\
\text { tahapnya memakai sedikit materi dan bacaan } \\
\text { c. Siswa dibimbing untuk melakukan keterampilan } \\
\text { tersebut dengan mengerjakan Kertas Kerja Siswa } \\
\text { d. Guru memberitakan pertanyaan siswa menjawab, } \\
\text { guru menunjuk beberapa siswa } \\
\text { e. Guru memberikan latihan mandiri kepada siswa } \\
\text { untuk membaca kelanjutan dari isi bacaan dengan } \\
\text { strategi metode PQ4R }\end{array}$ \\
\hline III & $\begin{array}{l}\text { PENUTUP } \\
\text { a. Merangkum pelajaran } \\
\text { b. Catatan }\end{array}$ & $\begin{array}{l}\text { Guru bersama-sama dengan siswa merangkum } \\
\text { materi pelajaran dengan cara membaca kesimpulan } \\
\text { yang telah dibuat secara klasikal. } \\
\text { a. Guru selama KBM, jangan membuat kesan yang } \\
\text { monoton } \\
\text { b. Guru hendaknya menentukan waktu kapan tiap- } \\
\text { tiap tahap dilaksanakan } \\
\text { c. Tetap mempertahankan motivasi siswa } \\
\text { d. Guru hendaknya memakai kata-kata yang mudah } \\
\text { dipahami siswa } \\
\text { e. Guru hendaknya membimbing siswa satu persatu } \\
\text { pada saat melakukan pelatihan }\end{array}$ \\
\hline
\end{tabular}

Diadaptasi dari Arends (1997: 67 dan 257)

\section{Data dan Temuan Penelitian Siklus I}

Pada akhir pembelajaran guru belum memberikan simpulan akhir karena terburu-terburu melaksanakan evaluasi. Siswa belum siap untuk mengerjakan evaluasi karen amasih ada yang mengumpulkan tugas individu dan LKS. Pada saat pelaksanaan evaluasi ada yang bermain-main dan bertanya kepada temannya. Adapun hasil tes akhir siklus I seperti pada table dibawah ini:

\section{Table 5 Hasil Tes Akhir Siklus I}

\begin{tabular}{|c|c|c|c|c|}
\hline \multirow[b]{2}{*}{ No } & \multirow[b]{2}{*}{ Nama Responden } & \multirow[b]{2}{*}{ Skor } & \multicolumn{2}{|c|}{ Keterangan } \\
\hline & & & Tuntas & $\begin{array}{c}\text { Tidak } \\
\text { Tuntas }\end{array}$ \\
\hline 1 & AHMAD AUFA R & 60 & & \\
\hline 2 & AHMAD SYAHTIRI & 80 & & \\
\hline 3 & AINUN NAIM & 60 & & \\
\hline 4 & ALPI BANROH & 60 & & \\
\hline 5 & AULIA NOVITA & 80 & & \\
\hline 6 & AZIZAH & 70 & & \\
\hline 7 & BAHARRUDIN Z A & 50 & & \\
\hline 8 & BIMO KIKO & 90 & & \\
\hline 9 & DINI ARTANTI & 80 & & \\
\hline 10 & FADILATUL H & 80 & & \\
\hline 11 & HANAYA KAMILO & 80 & & \\
\hline
\end{tabular}




\begin{tabular}{|l|l|l|l|l|}
\hline 12 & JUWITA APRIYANTI & 70 & & \\
\hline 13 & M. FAHMI & 60 & & \\
\hline 14 & M. RAHMADANI & 80 & & \\
\hline 15 & M. ARDIANTO & 60 & & \\
\hline 16 & M. ARIF SETYAWAN & 80 & & \\
\hline 17 & M. HAFI & 60 & & \\
\hline 18 & M. IKHWAN & 70 & & \\
\hline 19 & M. NUR FADHILLAH & 80 & & \\
\hline 20 & NAHEL & 80 & & \\
\hline 21 & NAJAH MAISYARAH & 80 & & \\
\hline 22 & NOR HELMANIAH & 60 & & \\
\hline 23 & PUTRI ADELIA & 80 & & \\
\hline 24 & RAHMADANIAH & 60 & & \\
\hline 25 & ROSA MAILIANA & 80 & & \\
\hline 26 & SHANDY PUTERA A & 60 & & \\
\hline 27 & SITI HALIMAH & 70 & & \\
\hline 28 & SITI NAJWA & 80 & & \\
\hline 29 & SITI NUR FADILA & 80 & & \\
\hline 30 & SITI RUKAYAH & 80 & & \\
\hline 31 & TIARA HOSINDA & 60 & & \\
\hline & RATA-RATA & $\mathbf{7 0 . 3 1}$ & & \\
\hline & PROSENTASE & & \\
\hline
\end{tabular}

Berdasarkan table 5, dapat dijelaskan bahwa hasil tes pada siklus I dari 22 siswa sebagai responden mencapai skor 2.250 dengan nilai rata-rata mencapai 70,31 sehingga 20 orang dinyatakan tuntas $(64,52 \%)$ dan 11 orang dinyatakan tidak tuntas belajar $(35,48 \%)$. Dengan mengacu pada standar ketuntasan minimal $85 \%$ secara klasikal perlu adanya siklus perbaikan (siklus II).

Penilaian evaluasi ada dua fokus yaitu pemahaman tiap-tiap paragraph dan isi bacaan secara keseluruhan. Adapun hasil pengamatan pelaksanaan pembelajaran pada siklus I adalah sebagai berikut:

1) Hasil rata-rata tes pemahaman Teks Cerita Inspiratif adalah 70,31

2) Ketuntasan belajar sebagai indikator pemahaman Teks Cerita Inspiratif secara klasikal sebesar $64,52 \%$ berada dibawah kriteria ketuntasan klasikal (85\%).

\section{Data dan Temuan Penelitian Siklus II}

Simpulan review yang dilakukan guru semu sebab review dipimpin oleh siswa. Guru memberikan simpulan akhir dan memberi penguatan terhadap materi yang telah disampaikan. 
Evaluasi dapat dilaksanakan dengan waktu yang cukup.Adapun hasil tes akhir Siklus II seperti tertera pada table dibawah ini.

Table 6 Hasil Tes Kahir Siklus II

\begin{tabular}{|c|c|c|c|c|}
\hline \multirow[b]{2}{*}{ No } & \multirow[b]{2}{*}{ Nama Responden } & \multirow[b]{2}{*}{ Skor } & \multicolumn{2}{|c|}{ Keterangan } \\
\hline & & & Tuntas & $\begin{array}{c}\text { Tidak } \\
\text { Tuntas } \\
\end{array}$ \\
\hline 1 & AHMAD AUFA R & 90 & & \\
\hline 2 & AHMAD SYAHTIRI & 90 & & \\
\hline 3 & AINUN NAIM & 60 & & \\
\hline 4 & ALPI BANROH & 80 & & \\
\hline 5 & AULIA NOVITA & 90 & & \\
\hline 6 & AZIZAH & 80 & & \\
\hline 7 & BAHARRUDIN Z A & 90 & & \\
\hline 8 & BIMO KIKO & 90 & & \\
\hline 9 & DINI ARTANTI & 80 & & \\
\hline 10 & FADILATUL H & 90 & & \\
\hline 11 & HANAYA KAMILO & 90 & & \\
\hline 12 & JUWITA APRIYANTI & 90 & & \\
\hline 13 & M. FAHMI & 90 & & \\
\hline 14 & M. RAHMADANI & 60 & & \\
\hline 15 & M. ARDIANTO & 80 & & \\
\hline 16 & M. ARIF SETYAWAN & 90 & & \\
\hline 17 & M. HAFI & 90 & & \\
\hline 18 & M. IKHWAN & 90 & & \\
\hline 19 & M. NUR FADHILLAH & 90 & & \\
\hline 20 & NAHEL & 90 & & \\
\hline 21 & NAJAH MAISYARAH & 80 & & \\
\hline 22 & NOR HELMANIAH & 90 & 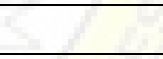 & \\
\hline 23 & PUTRI ADELIA & 60 & 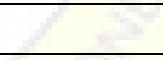 & \\
\hline 24 & RAHMADANIAH & 80 & & \\
\hline 25 & ROSA MAILIANA & 90 & & \\
\hline 26 & SHANDY PUTERA A & 90 & & \\
\hline 27 & SITI HALIMAH & 90 & & \\
\hline 28 & SITI NAJWA & 90 & & \\
\hline 29 & SITI NUR FADILA & 90 & & \\
\hline 30 & SITI RUKAYAH & 80 & & \\
\hline 31 & TIARA HOSINDA & 90 & & \\
\hline & JUMLAH SKOR & 2700 & 28 & 3 \\
\hline & RATA-RATA & 84.38 & & \\
\hline & PROSENTASE & & 90,32 & 9,68 \\
\hline
\end{tabular}

Berdasarkan table diatas dapat dijelaskan bahwa hasil tes pada Siklus II dari 31 siswa sebagai responden mencapai skor 2.700 dengan nilai rata-rata mencapai 84,38 sehingga 28 siswa dinyatakan 
tuntas $(90,32 \%)$ dan 3 siswa dinyatakan tidak tuntas belajar (9,68\%). Dengan mengacu pada standar ketuntasan minimal $85 \%$ secara klasikal telah mencapai ketuntasan yang dipersyaratkan sehingga tidak perlu adanya siklus perbaikan.

Penilaian evaluasi ada dua fokus yaitu pemahaman tiap-tiap paragraph dan isi bacaan secara keseluruhan. Adapun hasil pengamatan pelaksanaan pembelajaran pada siklus II adalah sebagai berikut:

1) Hasil rata-rata tes pemahaman Teks Cerita Inspiratif adalah 84,38

2) Ketuntasan belajar sebagai indikator pemahaman Teks Cerita Inspiratif secara klasikal sebesar $90,32 \%$ berada diatas kriteria ketuntasan klasikal $(85 \%)$

\section{SIMPULAN}

Berdasarkan paparan data, temuan data dan pembahasan hasil penelitian dapat disimpulkan bahwa:

1. peningkatan menemukan garis besar isi bacaan dengan menggunakan metode PQ4R pada siswa kelas IX-C di SMP Negeri 1 Martapura Semester Genap Tahun Pelajaran 2018/2019 dilaksanakan dengan cara sebagai berikut :

a. Pertama, guru memilih materi yang menarik sehingga siswa termotivasi untuk melaksanakan strategi belajar dengan metode PQ4R lebih aktif.

b. Kedua, untuk tugas individu maupun LKS harus lebih efektif agar tidak membuang waktu dan strategi belajar dengan metode PQ4R dapat berjalan dengan lancar.

c. Ketiga, guru lebih intensif membimbing siswa dalam strategi belajar dengan metode PQ4R. Baik strategi belajar dengan metode PQ4R membahas tugas individu, menyelesaikan LKS, maupun diskusi kelas untuk mempresentasikan hasil review siswa.

d. Keempat, guru sebaiknya mengalokasikan waktu dengan cermat agar strategi belajar dengan metode PQ4R berjalan lancar dan semua masalah dapat dibahas dengan tuntas.

2. Peningkatan kemampuan memahami Teks Cerita Inspiratif dapat dilihat dari beberapa hal. Hasil pengamatan aktivitas meningkat dari siklus I ke siklus II. Komponen yang berkualifikasi cukup pada siklus sbeelumnya meningkat menjadi kualifikasi cukup baik, begitu juga dari kualifikasi cukup baik menjadi baik. Hasil kemampuan siswa menyelesaikan LKS meningkat 16dari siklus I ke siklus II. Hasil rata-rata tes pemahaman terhadap Teks Cerita Inspiratif meningkat dari 14,08 dari siklus I ke siklus II (dari 70,31 menjadi 84,38). Ketuntasan belajar sebagai indikator 
peningatan pemahaman Teks Cerita Inspiratif secara klasikal juga meningkat 31,04\% dari siklus I ke siklus II (dari 59,28 menjadi 90,32\%).

\section{SARAN}

Berdasarkan uraian dan simpulan maka peneliti memberikan saran-saran sebagai berikut.

1) Bagi pendidik, peneliti mengharapkan agar bisa belajar dari penelitian ini dan mampu menerapkannya dalam proses belajar mengajar

2) Bagi peneliti selanjutnya, diharapkan dapat menggali lebih dalam dan lebih luas mengenai model pembelajaran.

\section{DAFTAR RUJUKAN}

Arends, Richardl. 1997. Classroom Instructional Management. New York: The Mc Graw - Hill Company

Arikunto, Suharsimi, dkk. 2007. Penelitian Tindakan Kelas. Jakarta: Bumi Aksara

Bunanta, Murti. 2005. Peran Perpustakaan Dalam Memotivasi Minat Dan Kegemaran Membaca Anak Dan Remaja (Kumpulan Materi Pokok). Dinas Pendidikan Dan Kebudayaan Prop. Jawa Timur.)

Madya, Suwarsih. 2006. Teori dan Praktik: Penelitian Tindakan. Bandung: Alfabeta.

Martutik. 2005. Dasar-Dasar Teori Membaca. Pendidikan Bahasa dan Sastra.Universitas Negeri Malang.

Nurhadi. 2006. Bagaimana Meningkatkan Kemampuan Membaca?Bandung : CV. Sinar Baru

Nuryatim. 2004. Tentang Membaca, Sumenep : Alternatif Computer Design

Peraturan Menteri Pendidikan Nasional Nomor 22 Tahun 2006 Tentang Standar Isi Untuk Satuan Pendidikan Dasar Dan Menengah. Jakarta: Dirjen Manajemen Pendidikan Dasar Dan Menengah. Depdiknas

Ranchman, Saiful, dkk. 2006. Penelitian Tindakan Kelas. Surabaya: SIC \& Dinas P dan K Provinsi Jawa Timur.

Sardiman, Arief S, dkk. 2006. Media Pendidikan. Jakarta: PT. Raja Grafindo Persada

Suyatno.2004. Teknik Pembelajaran Bahasa dan Sastra.Surabaya : SIC 
Trianto, 2007.Model-model Pembelajaran Inovatif Berorientasi Kostruktivistik. Jakarta: Prestasi Pustaka.

Wardani, I.G.A.K., dkk. 2005. Penelitian Tindakan Kelas. (Buku Materi Pokok. IDIK 4420/Modul 1-6).Jakarta : Pusat Penerbitan Universitas Terbuka.

Wiriatmadja, Rochiati. 2007. Metode Penelitian Tindakan Kelas. Bandung: PT. Remaja Rosdakarya.

Yohanes, Budinuryanta. 2005. Materi Pokok Pengajaran Keterampilan Berbahasa. Ebna 3303/3SKS/Modul 1-9. Jakarta. Depdikbud. Universitas Terbuka. 